\title{
Dampak Pembelajaran Daring terhadap Siswa usia 5-8 tahun
}

\author{
Nana Sutarna ${ }^{1 凶}$, Arrofa Acesta $^{2}$, Nika Cahyati ${ }^{3}$, Sendi Fauzi Giwangsa ${ }^{4}$, Dedi Iskandar ${ }^{5}$, \\ Harmawati ${ }^{6}$. \\ Pendidikan Guru Sekolah Dasar, Sekolah Tinggi Keguruan dan Ilmu Pendidikan Muhammadiyah \\ Kuningan $^{(1)}$ \\ Pendidikan Guru Sekolah Dasar, Universitas Kuningan(2) \\ Pendidikan Guru Pendidikan Anak Usia Dini, Sekolah Tinggi Keguruan dan Ilmu Pendidikan \\ Muhammadiyah Kuningan(3), \\ Pendidikan Guru Sekolah Dasar, Universitas Pendidikan Indonesia(4) \\ Pendidikan Jasmani Kesehatan dan Rekreasi, Sekolah Tinggi Keguruan dan Ilmu Pendidikan \\ Muhammadiyah Kuningan(5) \\ Pendidikan Guru Sekolah Dasar, Universitas Buana Perjuangan Karawang(6) \\ DOI: $\underline{10.31004 / \text { obsesi.v5i2.1265 }}$
}

\begin{abstract}
Abstrak
Dampak yang terjadi saat pandemi covid 19 bukan hanya pada sector ekonomi, namun juga dalam pendidikan, salah satunya adalah mengakibatkan pembelajaran daring, banyak dampak yang di rasakan saat pembelajaran daring, dampak negative lebih menonjol dari pada dampak positif saat menjalani pembelajaran daring. Tujuan penelitian ini adalah untuk mengetahui dampak pembelajaran daring terhadap siswa usia 5-8 tahun saat pandemi covid 19. Metode penelitian ini adalah menggunakan metode kualitatif fenomenologis, data di peroleh melalui angket, subjek dari penelitian ini adalah orang tua yang memiliki anak usia 5-8 tahun guru PAUD dan Guru SD tingkat rendah Kecamatan Darma Kabupaten Kuningan. Hasil penelitian ini adalah bahwa pembelajaran daring memiliki beberapa dampak pada siswa yaitu siswa menjadi kurang bersosialisasi, siswa mengalami kekerasan verbal, kurangnya kedisiplinan dalam pembelajaran di rumah, fasilitas pembelajaran yang tidak memadai, dan tidak tercapai tujuan pembelajaran pada siswa.
\end{abstract}

Kata Kunci: Pembelajaran daring, siswa usia 5-8 Tahun

\begin{abstract}
The impact that occurred during the Covid 19 pandemic was not only in the economic sector, but also in education, one of which was the result of online learning, many of the impacts were felt when learning online, the negative impact was more prominent than the positive impact when undergoing online learning. The purpose of this study was to determine the impact of online learning on students aged 5-8 years during the COVID-19 pandemic. This research method is to use a phenomenological qualitative method, data is obtained through a questionnaire, the subject of this study is parents who have children aged 5-8. 8 years of early childhood teachers and elementary school teachers at low level, Darma District, Kuningan Regency. The results of this study are that online learning has several impacts on students, namely students becoming less socialized, students experiencing verbal violence, lack of discipline in learning at home, inadequate learning facilities, and not achieving learning objectives for students.
\end{abstract}

Keywords: online learning, 5-8 years old students.

Copyright (c) 2021 Nana Sutarna, Arrofa Acesta, Nika Cahyati, Sendi Fauzi Giwangsa, Dedi Iskandar, Harmawati.

$\triangle$ Corresponding author :

Email Address : nana@upmk.ac.id (Kuningan, Indonesia)

Received 15 April 2021, Accepted 26 April 2021, Published 27 April 2021 


\section{PENDAHULUAN}

Saat ini negara kita sedang di landa musibah besar, yaitu adanya wabah atau virus yang menyerang manusia di seluruh dunia yaitu dikenal dengan covid 19, dimana wabah atau virus ini menyrang siapapun, sehingga menyebabkan Negara kita Indinesia juga harus sangat waspada, dan menetapkan untuk melakukan kegiatan di rumah saja, serta harus social distancing untuk menjaga agar memperlambat penyebaran covid 19. Menurut WHO (WHO, 2019) Coronavirus merupakan keluarga besar virus yang menyebabkan penyakit pada manusia dan hewan. Pada manusia biasanya menyebabkan penyakit infeksi saluran pernapasan, mulai flu biasa hingga penyakit yang serius seperti Middle East Respiratory Syndrome (MERS) dan Sindrom Pernafasan Akut Berat/ Severe Acute Respiratory Syndrome (SARS). Coronavirus jenis baru yang ditemukan pada manusia sejak kejadian luar biasa muncul di Wuhan Cina, pada Desember 2019, kemudian diberi nama Severe Acute Respiratory Syndrome Coronavirus 2 (SARS-COV2), dan menyebabkan penyakit Coronavirus Disease-2019 (COVID-19).

Adanya pandemi covid 19 membuat semua sarana mati atau di tutup sementara, termasuk kegiatan belajar mengajar, sejak Gubernur Jawa Barat menetapkan status Keadaan Tertentu Darurat Bencana Wabah Virus Corona (Covid-19) di Jawa Barat yang tertuang dalam SK Gubernur Nomor 400/27/hukham, tanggal 13 Maret 2020 (Gubernur Provinsi Jawa Barat, 2020). Agar siswa dapat belajar di rumah, demi keamanan dan kesehatan kita semua, hal ini tentunya berdampak untuk orang tua, dimana orang tua harus memberikan pembelajaran pada anaknya di rumah. Tentu terjadi berbagai pendapat mengenai hal ini, banyak orang tua yang mengungkapkan bahwa mereka merasa keberatan ketika anak belajar di rumah, karena di rumah anak merasa bukan waktunya belajar namun mereka cenderung menyukai bermain saat di rumah, walaupun di situasi pamdemi seperti ini.

Pandemi covid 19 merupakan krisis kesehatan yang sedang terjadi di dunia saat ini, hal ini telah menjadi berbincangan dunia, seperti yang diberitakan (Nafilah sri nagita, 2020) virus ini sangat menjadi permasalahan dunia saat ini dangan sangat cepat sekali menyebar dan meluas sampai menyebar ke seluruh dunia dan berdampak ke berbagai sector (Khasanah et al., 2020). Salah satu sector yang mengalami dampak dari pandemi ini adalah bidang pendidikan, banyak negara yang memutuskan untuk menutup sekolah mulai dari pendidikan anak usia dini sampai perguruan tinggi, demi memutuskan rantai penularan virus covid 19, dan proses pembelajaran dilakukan dilakukan secara daring sebagai upaya menghindari kegiatan tatap muka.

Pendidikan saat ini dipaksa untuk harus bisa mengikuti perkembangan dan kemajuan teknologi. Penguasaan teknologi harus dimiliki oleh setiap orang tua, siswa dan guru. Tidak semua orang tua, siswa dan guru mengenal teknologi. Pada umumnya guru senior belum mampu menguasai teknologi, ada yang mau belajar penggunaan teknologi dan ada yang tidak mau belajar akan penggunaan teknologi. Masih banyak para guru yang belum bisa memahami tentang cara menggunakan teknologi yang semakin canggih, maka hal ini juga menjadi salah satu kendala dalam pembelajaran daring saat pandemi ini (Khasanah et al., 2020).

Pembelajaran daring pada siswa membuat siswa dapat memiliki keleluasaan waktu belajar, dapat belajar dimanapun dan kapanpun, penggunaan aplikaasi belajar dapat dilakukan oleh berbagai aplikasi, seperti classroom, video converence, telepon atau live chat, zoom maupun melalui whatsapp group. Pembelajaran daring merupakan sebuah inovasi untuk menjawab tantangan mengenai model pembelajaran inovatif, namun keberhasilan suatu model pembelajaran tergantung pada karakteristik siswa, seperti yang diungkapkan (W. A. F. Dewi, 2020) dari semua literatur dalam e-learning mengindikasikan bahwa tidak semua peserta didik akan sukses dalam pembelajaran online. Ini dikarenakan faktor lingkungan belajar dan karakteristik peserta didik.

Pembelajaran daring adalah salah satu alternative agar siswa tetap mendapatkan pendidikan waalaau dalam keadaan belajar di rumah, penelitian (Napitupulu, Rodame Monitorir, 2020) menjelaskan bahwa pembelajaran daring memiliki banyak kendala 
khususnya bagi siswa usia 5-6 tahun, penyebanya adalah siswa usia ini masih memerlukan pendampingan secara utuh dari guru atau orang tua, namun masih banyak orang tua siswa yang tidak memiliki smartphone untuk menunjang proses belajar, penenaman nilai karakter tidak diajarkan dirumah, serta pembelajaran daring hanya bersifat pemberian tugas oleh guru karena terbatasnya cara memberikan pemahaman terhadap siswa.

Siswa usia 5-8 tahun memerlukan pendampingan ekstra dalam proses pembelajaran, karena pada umumnya anak usis ini memiliki karakteristik rasa ingin tahu yang besar, memiliki pribadi yang unik, egosentris, memiliki imajinasi yang tinggi, dan memiliki daya konsentrasi yang rendah (Haerudin, 2018). Hal ini menunjukan bahwa anak usia 5-8 tahun harus didampingi secara serius dalam proses pembelajaran, agar seluruh aspek perkembangan dapat dicapai, sehingga anak usia ini tidak hanya dapat diberikan pembelajaran hanya dengan bentuk penugasan, karena anak usia ini bukan hanya bidaang kognitif saja yang harus di tingkatkan, namun semua aspek perkembangan harus dapat di tingkatkan, maka selain orang tua, guru juga sangat berperan penting terhadap tercapainya perkembangan anak.

Sekolah dasar harusnya menjadi tempat dasar penanaman nilai-nilai karakter yang mungkin tidak dapat diajarkan dirumah. Namun, karena dampak pendemi ini siswa menjadi kesulitan menerima pendidikan karakter secara langsung dari guru-gurunya di sekolah. Pembelajaran daring ditingkat sekolah dasar biasanya hanya diberikan tugas oleh guru tanpa disertai penjelasan mengenai materinya terlebih dahulu. Sehingga proses belajar siswa hanya bergantung pada orang tua. Akan tetapi, orangtua terkadang tidak bisa sepenuhnya membantu karena terkendala waktu, pengetahuan, dan keahlian dalam teknologi. Hal ini juga menjadi kendala dalam pembelajaran daring saat pandemi covid 19 saat ini. Tujuan dari penelitian ini adalah untuk mendapatkan informasi mengenai dampak COVID-19 terhadap implementasi pembelajaran daring di sekolah dasar. Apakah pembelajaran daring pada sekolah dasar bisa dilakukan dengan baik dan efektif.

\section{METODOLOGI}

Metode penelitian yang digunakan adalah metode penelitian kualitatif. Jenis penelitiannya mengarah pada kajian fenomenologis yang memiliki perhatian khusus terhadap fenomena yang diteliti yaitu fenomena pembelajaran daring saat pandemi covid 19. Penelitian ini menganalisis bagaimana dampk pembelajaran daring terhadap siswa usia 5-8 tahun. Penelitian ini fokus terhadap kegiatan subjek penelitian, mengugkapkan permasalahan, memaparkan data, menganalisis data. Alasan pemilihan subyek dilatar belakangi oleh subyek adalah orang terdekat yang mengetahui perkembangan anaknya sehingga memilih subyek orang tua atau ibu. Subyek yang dipilih adalah orang tua siswa usia 5-8 tahun yang sedang mendampingi anaknya untuk pembelajaran daring di Kecamatan Darma Kabupaten Kuningan.

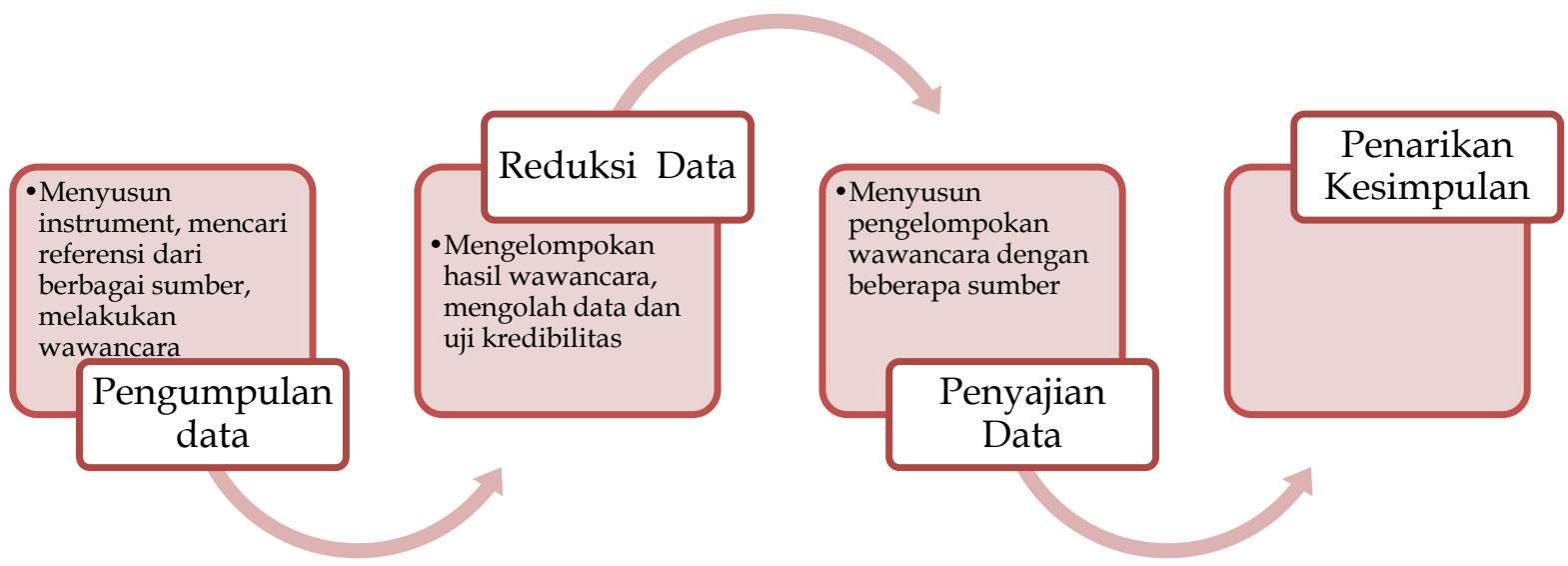

Gambar 1. Langkah-langkah penelitian 
Teknik pengumpulan data yang digunakan adalah wawancara dan data dianalisis dengan menggunakan tematik, yaitu teknik analisis yang menekankan pada penyusunan koding dengan mengacu pada pertanyaan penelitian yang telah ditetapkan, sehingga tematema yang tersusun sesuai dengan pertanyaan penelitian tersebut dan menjadi acuan dalam memaparkan fenomena yang terjadi, peneliti melakukan wawancara menggunakan telepon dikarenakan terbatasi adanya masa pandemi, dalam melakukan wawancara pada satu partisipan kurang lebih 20 menit dengan menggunakan wawancara semi terstuktur. Analisis data melalui pengumpulan data dengan menyusun instrument wawancara, mencarai referensi dari berbagai sumber, serta melakukan wawancara mendalam dengan responden, selanjutnya reduksi data yaitu mengelompokan hasil wawancara, mengolah data dan uji kredibilitas, kemudian penyajian data dengan menyusun pengelompokan wawancara dengan beberapa sumber dan di narasikan, terakhir penarikan kesimpulan mengenai dampak pembelajaran daring pada siswa usia 5-8 tahun.

\section{HASIL DAN PEMBAHASAN}

Dampak pandemi ini pada awalnya hanya berdampak pada dunia ekonomi yang mulai turun, namun kini dampoaknya dirasakan pula oleh dunia pendidikan. Kebijakan yang diambil oleh berbagai negara yaitu dengan mengganti pembelajaran yang biasanya dilakukan dengan tatap muka kini digantikan secara daring sebagai alternative proses pendidikan bagi siswa. Aktivitas yang melibatkan kumpulan orang-orang kini dibatasi seperti bersekolah, bekerja, beribadah, penutupan tempat wisata, maupun tempat perbelanjaan. Hal ini sebagai upaya untuk memutus rantai penularan virus covid 19. Menteri Anwar Makarim menerbitkan Surat Edaran Nomor 3 Tahun 2020 pada Satuan Pendidikan dan Nomor 36962/MPK.A/HK/2020 tentang Pelaksanaan Pendidikan dalam Masa Darurat Coronavirus Disease (COVID-19) maka kegaiatan belajar dilakukan secara daring (online) dalam rangka pencegahan penyebaran coronavirus disease (COVID0-19). (Menteri Pendidikan, 2020).

Dengan kebijaksanaan untuk belajar di rumah menyebabkan para orang tua juga harus menyesuaikan engan metopde yang baru tersebut. Dalam pelaksanaannya, pembelajaran di rumah dengan metode daring tidaklah mudah. Faktor kurangnya semangat anak dan kurangnya kemampuan orang tua dalam mendampingi anak menjadi tantangan dalam penerapan metode pembiasaan. Tidak semua orang tua bisa menggunakan aplikasi pembelajaran yang baru, dan juga tidak banyak orang tua yang menggantikan sebagai guru di rumah. Orang tua sering tidak sabar dan tidak telaten dalam menghadapi ankanya di rumah yang kadang malah sering dibentak-bentak atau dimarahi yang dapat menimbulkan efek yang tidak baik bagi anak. Dengan situasi dan kondisi yang tidak kondusif tersebut membuat anak menjadi jenuh di rumah karena tidak bisa ketemu dengan teman-teman di sekolah seperti biasanya, dan kurangnya motivasi untuk belajar. Pembelajaran di rumah sering monoton, karena biasanya di sekolah guru menyampaikan pembelajaran diselingi nyanyi, tepuk tangan, cerita dan dongeng serta kreatifitas lainnya. Emosi anak yang belum stabil dan belum bisa mengontrol dirinya dengan baik serta kemampuan konunikasi yang terbatas sehingga sulit menyampaikan apa yang dia rasakan. Dengan adanya perubahan atmosfir dan lingkungan serta tatanan baru, yang biasanya melakukan pembelajaran bersama teman-teman di sekolah yang sangat menyenangkan dan penuh kreatifitas, sekarang dengan tiba-tiba harus dilakukan sendiri di rumah dirasakan sangat kurang menarik dan membosankan.

Pembelajaran daring yang saat ini dilaksanakan ternyata sangat berpengaruh terhadap perilaku siswa, siswa menjadi kurang bersosialiasi karena pembelajaran terbatas hanya di rumah tidak bertemu teman, siswa cenderung lebih emosional, siswa juga mengalami kekerasan verbal karena proses pembelajaran, siswa cenderung tidak disiplin dalam melakukan pembelajaran. Hal ini merupakan dampak negative dari pembelajaran daring yang saat ini sedang di implementasikan masyarakat Indonesia, kendala jaringan internet, kurangnya kemampuan masyarakat menggunakan aplikasi pembelajaran daring, waktu 
orang tua untuk mengajari anak mereka serta kurangnya pengetahuan orang tua saat mengajari anak juga menjadi kendala saat pembelajaran daring dilakukan, prestasi siswa juga tidak Nampak, penyebabnya adalah tidak ada penilaian yang menilai proses karena semua kegiatan pembelajaran dilakukan dirumah dengan pengawasan orang tua. Terdapat 5 hal yang menjadi sorotan dampak pembelajaran daring terhadap siswa diantaranya;

\section{Siswa menjadi kurang bersosialisasi}

Pembelajaran daring membuat siswa sering belajar di rumah dan jika siswa tersebut tinggal di kota maka akan sangat jarang sekali ia berkumpul dengan teman sebaya mereka, dan banyak siswa yang menghabiskan waktunya di rumah dan hanya bermain gadget, sehingga kehidupan sosial anak terganggu, karena anak tidak bertemu dengan teman mereka, bahkan hanya bertemu dengan keluarganya, keadaan seperti ini membuat siswa kurang bersosialisasi padahal anak usia 5-8 tahun sangat membutuhkan orang lain untuk belajar bersosialiasi gunanya untuk menumbuhkan rasa kebersamaan, gotong royong, empati, hal seperti ini perlu di tanamkan sejak dini, agar setelah anak dewasa anak akan memiliki karakteristik seperti itu (Santrock, 2014). Anak akan lebih kesulitan menghadapi lingkungannya setelah anak menjadi kurang berssosialisasi, kurangnya percaya diri anak. Sekolah diliburkan terlalu lama membuat anak- anak jenuh, anak-anak mulai jenuh di rumah dan menginginkan segera ke sekolah bermain dengan teman- temannya, siswa terbiasa berada di sekolah untuk berinteraksi dengan teman-temannya, bermain dan bercanda gurau dengan teman- temannya serta bertatap muka dengan para gurunya. Kemudian murid akan kehilangan jiwa sosial, jika di sekolah mereka bisa bermain berinteraksi dnegan temantemnanya tetapi kali ini mereka tidak bisa dan hanya sendiri di rumah bersama orang tua, interaksi dengan sesama teman, guru dan orang-orang disekolah akan menjadi berkurang(Purwanto et al., 2017). Anak juga cenderung tidak mendengarkan arahaan dari orang tua, karena hilangnya sosok yang dikagumi oleh siswa, yaitu guru, pada umumnya anak menganggap bahwa ketika harus belajar dirumah, itu hanya menjadi beban mereka bahkan banyak yang mengatakan bahwa tidak jarang orang tua yang mengerjakan tugastugas anaknya demi tugas anak mereka selesai, hal ini menunjjukan dampak negative dari pembelajaran daring yang terjadi sampai saat ini.

Hasil analisis menunjukan bahwa secara umum perilaku sosial emosiaonal anak selama pembelajaran daring adalah anak kurang bersikap kooperatif karena anak jarang bermain bersama, kurangnya sikap toleransi kurangnya bersosialisasi dengan teman terbatasi adanya belajar dirumah (Kusuma \& Sutapa, 2020). Anak jarang bermain atau jarang bersosialisasi ternayat memiliki dampak yang negative bagi anak, hasilnya anak bersikap kurang kooperatif serta kurang memiliki rasa tolerannsi, penyebanya adalah anak kurang mengenal lingkungan, bahkan permainannya hanya sebatas gadget yang juga bisa menyebabkan anak lebih emosional dari pada anak yang tidak bermain gadget (Damayanti et al., 2020).

\section{Siswa mengalami kekerasan verbal}

Pembelajaran daring pada siswa di saat pandemi cenderung meningkatkan kekerasan verbal di rumah, Hampir satu tahun lamanya, kegiatan belajar mengajar dilakukan dari rumah masing-masing secara daring. Orang tua berperan penting untuk mendampingi, mengawasi, bahkan menjadi guru anaknya untuk melakukan kegiatan pembelajaran. Pola asuh ini menjadi hal yang baru bagi orang tua (P. A. S. C. Dewi \& Khotimah, 2020). Tidak sedikit orang tua yang belum terbiasa melakukan aktivitas ini menjadi tersulut emosi sehingga terjadilah kekerasan pada anak yang dilakukan oleh orang tua. Ditambah orang tua yang harus sambil bekerja secara work form home dan juga mengerjakan pekerjaan rumah lainnya. Tentunya hal ini membuat emosi orang tua menjadi sering tidak terkontrol (Haerudin et al., 2020). Komisi Perlindungan Anak Indonesia (KPAI) melakukan survei tentang pola asuh ibu selama pandemi COVID-19. Hasil yang mengejutkan bahwa pola asuh tersebut ada kaitannya 
dengan kekerasan pada anak baik secara fisik dan psikis. Survei dilakukan secara terpisah antara orang tua perempuan dan orang tua laki-laki. Hasil survei menunjukkan bahwa orang tua laki-laki sebesar 25,6 persen, sedangkan orang tua perempuan sebesar 74,4 persen (KPAI, 2021).

Kekerasan pada anak adalah suatu bentuk perilaku yang dilakukan dengan sengaja untuk menyakiti fisik atau psikis seorang anak. Tujuannya adalah tak lain untuk melukai, merusak, dan merugikan anak. Berdasarkan survei KPAI, bentuk kekerasan pada anak secara fisik ada berbagai macam. Seperti menarik, memukul, mencubit, dan menjewer. Ada 42,5 persen ibu yang melakukan, sedangkan sisanya sebanyak 32,3 persen dilakukan oleh ayah. Sementara kekerasan psikis seperti dibentak, dibandingkan dengan anak yang lain, dimarahi, dan dipelototi tak luput terjadi pada anak. Sebanyak 73 persen ibu melakukan kekerasan psikis, dan sisanya 69,6 persen dilakukan oleh ayah (KPAI, 2021). Anak-anak lebih mungkin mengalami masalah belajar dan perilaku ketika tinggal dengan orang tua yang mengalami masalah kesehatan mental atau penyalahgunaan zat. Depresi ibu juga menjadi penentu utama buruknya perkembangan anak usia dini. Hal ini terkait dengan dan sama pentingnya dengan fungsi keluarga, gaya pengasuhan, dan keterlibatan. Anak sangat peka terhadap emosi orang lain, terutama emosi anggota keluarga mereka (Santrock, 2007). Menyaksikan adegan kekerasan dan perselisihan verbal atau fisik memiliki efek negatif langsung dengan konsekuensi jangka panjang. Hal ini menunjukan pola asuh atau keterlibatan orang tua sangat penting bagi perkembangan anak, terutama saat pandemi, keterlibatan orang tua sangat diperlukan dalam mendampingi anak selama pembelajaran di rumah (Cahyati \& Kusumah, 2020). Orang tua cenderung memberikan kekerasan verbal yang tidak disadari saat berlangsungnya pembelajaran secara daring saat pandemi, mengucapkan kata-kata kasar saat anak tidak mengerjakan tugas, sehingga anak tidak akan tertarik untuk melakukan pembelajaran, hal ini juga akan membuat orang tua semakin kesal pada anaknya sehingga orang tua mengganggap anaknya tidak mampu melakukan pembelajaran di rumah, padahal perlunya kesabaran yang harus dilakukan orang tua sehingga pembelajaran di rumah akan dapat meningkatkan attachment atau kelekatan bagi orang tua dan anak.

\section{Kurangnya kedisiplinan dalam pembelajaran di rumah}

Disiplin merupakan faktor utama untuk mencapai kesuksesan dalam kegiatan pembelajaran dirumah, melalui sikap disiplin maka setiap siswa akan menciptakan rasa nyaman dan aman untuk belajar baik bagi dirinya sendiri, maupun bagi siswa lain yang ada di lingkungan sekolah (Kurniasari et al., 2020). Sikap disiplin tentu tidak akan tumbuh begitu saja pada diri siswa tanpa didasari dengan penegakkan peraturan yang efektif oleh pihak sekolah, melalui penegakan peraturan yang berupa tata tertib sekolah. Kedisiplinan merupakan salah satu yang harus ditanamkan ke dalam diri siswa oleh pendidik. Jika sifat kedisiplinan pada diri siswa telah tertanam, maka sifat kedisiplinan tersebut akan dapat diterapkan dalam berbagai urusan seperti dalam kebiasaan kegiatan belajar. Kedisiplinan yang dimiliki siswa merupakan bekal dalam bentuk sikap dan kepribadian yang handal dan mandiri dalam menghadapi masalah hidup dan kehidupan baik di sekolah maupun masyarakat. Berbicara masalah kedisiplinan siswa biasanya ada kaitannya dengan istilah tata tertib, yang berarti perangkat peraturan yang berlaku untuk menciptakan kondisi yang tertib dan teratur (Cahyati, 2018). Kesuksesan belajar sebenarnya tidak terlepas dari kedisiplinan siswa, siswa dikatakan disiplin dalam belajar apabila telah terbiasa melakukan kegiatan belajar tepat waktu, tempat, dan menurut peraturan-peraturan yang ada. Untuk membentuk kedisiplinan siswa perlu disusun tata tertib yang mengikat berikut dengan sanksi jika melanggarnya agar terbiasa melakukan sesuatu yang sesuai dengan aturan yang ada, sehingga dengan kebiasaan mentaati tata tertib akan tertanam nilai kedisiplinan dalam diri siswa. Saat pembelajaran selama pandemi, siswa pada umumnya mengalami penurunan kedisiplinan saatmelakukan pembelajaran, siswa cenderung tidak antusias saat melakukan pembelajaran secara daring, penyebanya adalah kebosanan siswa ketika tidak bertemu 
dengan temamnya, pada umumnya siswa merasa bahwa tugas selama pandemi hanya membebani mereka, karena mereka menganggap bahwa ketika tidak bersekolah maka tidak perlu belajar.

Dalam pelaksanaannya, pembelajaran di rumah dengan metode daring tidaklah mudah. Faktor kurangnya semangat anak dan kurangnya kemampuan orang tua dalam mendampingi anak menjadi tantangan dalam penerapan metode pembiasaan. Tidak semua orang tua bisa menggunakan aplikasi pembelajaran yang baru, dan juga tidak banyak orang tua yang menggantikan sebagai guru di rumah. Orang tua sering tidak sabar dan tidak telaten dalam menghadapi anakanya di rumah yang kadang malah sering dibentak- bentak atau dimarahi yang dapat menimbulkan efek yang tidak baik bagi anak. Dengan situasi dan kondisi yang tidak kondusif tersebut membuat anak menjadi semakin jenuh di rumah karena tidak bisa bertemu dengan teman-teman di sekolah seperti biasanya, serta kurangnya motivasi untuk belajar. Pembelajaran di rumah bersifat konsnntekstual yang hanya mengerjakan tugas, tanpa ada pengajaran seperti padaumumnya di sekolah, karena biasanya di sekolah guru menyampaikan pembelajaran diselingi nyanyi, tepuk tangan, cerita dan dongeng serta kreatifitas lainnya. Emosi anak yang belum stabil dan belum bisa mengontrol dirinya dengan baik serta kemampuan konunikasi yang terbatas sehingga sulit menyampaikan apa yang dia rasakan.

Jika kedua orang tua sama-sama sibuk bekerja, sehingga akan lebih sulit melakukan pembelajaran di rumah. Meskipun ada asisten rumah tangga, tentu sangat tidak mudah seorang asisten rumah tangga bisa mengikuti metode pembelajaran melalui jaringan internet, masalah yang terjadi yaitu kurangnya kedisiplinan siswa dalam melakukan pembelajaran saat daring(Pramana, 2020). Pembelajaran daring terlalu lama membuaat siswa merasa jenuh mengenai aktivitas yang dilakukan di rumah, hal ini menimbulkan kurangnya disiplin pada siswa saat pembelajaran daring, bahkan banyak yang menyelesaikan pembelajaran oleh orang tuanya, bukan oleh anak, penyebabnya adalah anak sudah tidak mau lagi atau sudah merasa bosan data mendapatkan penugasan dari guru.

\section{Fasilitas pembelajaran yang tidak memadai}

Fasilitas teknologi yang dibutuhkan saat pembelajaran daring tidak semua siswa memilikinya, tidak memiliki gadget ataupun terbatasnya sinyal juga menjadi kendala di Kecamatan Darma, karena pada umumnya masyarakat Darma tinggal di pelosok yang jauh dari jangkauan sinyal, kemudian pengetahuan orang tua mengenai teknologi juga sangat rendah, karena banyak orang tua yang memiliki pekerjaan sebagai petani dan tidak menguasai teknologi, sehingga hal ini menjadi kendala bagi siswa untuk melakukan pembelajaran secara daring. Minimnya pengetahuan mengenai penggunaan teknologi dan pengeluaran yang cukup besar menjadi kendala proses pembelajaran berlangsung(Mastura \& Santaria, 2020). Tantangan lain dalam proses pembelajaran di rumah adalah pengaruh dari penggunaan jaringan internet. Karena anak- anak menghabiskan lebih banyak waktu online, mereka dapat terkena lebih banyak iklan yang dapat mempromosikan makanan tidak sehat, stereotip gender atau materi yang tidak sesuai usia. Dengan adanya konten- konten yang tidak sesuai atau adanya bullying yang justru akan menimbulkan masalah baru bagi anak. Maka peran orang tua sangatlah penting untuk mendampingi ketika menggunakan perangkat internet atau pembelajaran online. Dengan metode pmbelajaran yang baru dan terkesan mendadak menimbulkan masalah bagi guru untuk menyesuaikannya, baik dari segi kurikulum sehingga harus menyusun kurikulum yang sesuai dengan kondisi pandemi, juga penggunaan metode pembelajaran daring yang belum tentu dikuasai oleh para guru. Belum lagi mengenai biaya "kuota" internet yang harus dikeluarkan oleh guru maupun orang tua siswa, apakah atas biaya sendiri atau biaya oleh institusi tempat mengajar. Proses pembelajaran melalui platform internet baik lewat whatsApp, zoom meeting atau dengan cara lainnya tentu tidak akan maksimal dalam memberi materi belajar jika dibanding tatap muka langsung di sekolah. Guru juga tidak bisa memantau langsung aktifitas anak seperti saat 
waktu di sekolah. Pembelajaran online kadang terkendala masalah sinyal yang kadang tidak stabil sehingga mengganggu proses pengajaran, dan hal ini kalau sering ditemukan maka akan menimbulkan kejengkelan dan gangguan kesehatan mental baik bagi guru, siswa dan orang tua (Pramana, 2020). Sehingga dalam menghadapi metode baru pembelajaran di era pandemi COVID-19 dibutuhkan kesabaran dan kecermatan dari semua pihak terutama oleh guru agar dapat menemukan solusi dan innovasi baru untuk tercapainya proses belajarmengajar dengan baik.

\section{Tidak tercapai tujuan pembelajaran pada siswa}

Pembelajaran selama pandemi berubah yaitu dengan menggunakan jaringan saat pembelajaran berlangsung yang dilakukan secara jarak jauh. Hal ini memberikan dampak pada guru karena kurang maksimal dalam memberikan materi pembelajaran dan terganggunya proses pembelajaran yang menyebabkan tidak tercapai tujuan pembelajaran yang diharapkan. Sehingga menjadikan materi tidak tuntas dan penggunaan media pembelajaran dalam pembelajaran daring tidak maksimal. Penilaian siswa pun terkendala dengan sekedar penilaian kognitif (Sari et al., 2021). PAda umumnya guru hanya memberikan tugas pada siswa melalui Whatsapp grup tanpa memberikan penjelasan yang membuat anak paham, jadi orang tua terpaksa harus memahami materi terlebih dahulu, sebelum di tugaskan ke anak. Karena terkendalanya pengetahuan mengenai teknologi, orang tua dan guru masih terbatas dalam memberikan penjelasan mengenai materi yang akan diajarkan yang menimbulkan kurangnya pemahaman siswa terhadap tugas yang di berikan.

Adapun kerugian siswa pada proses penilaian yaitu, ada kerugian yang mendasar bagi para murid ketika terjadi penutupan pada sekolah (Purwanto et al., 2017). Banyak juga kegiatan ujian sekolah maupun ujian negara yang mestinya dapat dilakukan oleh para murid pada kondisi normal, sekarang dengan mendadak karena dampak Covid-19, maka ujian tersebut dibatalkan ataupun ditunda. Penilaian internal bagi sekolah mungkin dianggap kurang, akan tetapi bagi keluarga murid informasi penilaian murid itu sangatlah penting (Sari et al., 2021). Ada yang menganggap hilangnya informasi penilaian murid juga sangat berarti bagi keberlangsungan masa depan murid. Misalkan saja target-target skill maupun keahlian tertentu yang mestinya tahun ini mendapatkan penilaian, sehingga berdampak untuk tahun yang akan datang.

Penilaian yang dilakukan masih bersifat kognitif, tidak melihat proses pembelajaran, bahkan sebenarnya guru tidak mengetahui hasil penugasan itu adalah benar-benar hasil karya anak, atau bahkan hasil karya orang tua, sehingga hal ini menunjukan penilaian terhadap siswa kurang efektif dan tidak tercapainya tujuan pembelajaran. Penelitian (Suhendro, 2020) salah satu strategi dalam melakukan pembelajaran saat pandemi ialah pembelajaran secara daring dan luring, yaitu pembelajaran secara daring bersifat penugasan melalui Whatsapp grup dan pembelajaran luring ialah melalui kunjungan kerumah-rumah atau home visit. Namun dalam kegiatan home visit juga terkendala dengan jarak, di kecamatan Darma dari desa ke desa lainnya akan menempuh jarak yang luamayan jauh, sehingga hal ini pula menjadi tantangan bagi guru untuk memberikan pembelajaran pada siswa secara utuh. Namun hal ini juga menjadi masalah ketika akan melakukan home visit dengan jarak yang cukup jauh.

Pembelajaran daring merupakan suatu perubahan teknologi terbaru yang dapat diandalkan ketika situasi pandemi seperti ini, namun sebaiknya dapat mencari alternative lain, sehingga semua dampak negative yang ada dapat diminimaliasir sehingga akan tetap tercapai tujuan pembelajaran.

\section{SIMPULAN}

Pembelajaran daring sangat berdampak terhadap siswa usia 5-8 tahun, hasil penelitian menunjukan bahwa siswa menjadi kurang bersosialiasi , siswa mengalami kekerasan verbal, kurangnya kedisiplinan dalam pembelajaran di rumah, fasilitas pembelajaran yang tidak memadai, tidak tercapai tujuan pembelajaran pada siswa, hal ini memberikan dampak pada 
guru karena kurang maksimal dalam memberikan materi pembelajaran dan terganggunya proses pembelajaran yang menyebabkan tidak tercapai tujuan pembelajaran yang diharapkan. Sehingga menjadikan materi tidak tuntas dan penggunaan media pembelajaran dalam pembelajaran daring tidak maksimal. Hasil penelitian ini bisa dijadikan sebagai bahan referensi atau acuan dalam mengevaluasi pelaksanaan pembelajaran daring terutama untuk siswa uusia 5-8 tahun.

\section{UCAPAN TERIMA KASIH}

Terimakasih kepada pihak lembaga yang telah memfasilitasi penelitian ini dan kepada responden yang telah membantu keberlangsungan penelitian, sehingga menanmbahkan pengetahuan bagi para pembaca dalam menghadapi pembelajaran daring di masa covid 19 .

\section{DAFTAR PUSTAKA}

Cahyati, N. (2018). Penggunaan Media Audio Visual Terhadap Karakter Tanggung Jawab Anak Usia 5-6 Tahun. Jurnal Golden Age, 2(02), 75. https:// doi.org/10.29408/goldenage.v2i02.1033

Cahyati, N., \& Kusumah, R. (2020). The Role of Parents in Applying Learning at Home During the Covid Pandemic 19. Journal Golden Age, Universitas Hamzanwadi, 04(1), 4-6.

Damayanti, E., Ahmad, A., \& Bara, A. (2020). Dampak Negatif Penggunaan Gadget Berdasarkan Aspek Perkembangan Anak Di Sorowako. Martabat: Jurnal Perempuan Dan Anak, 4(1), 1-22. https:// doi.org/10.21274/martabat.2020.4.1.1-22

Dewi, P. A. S. C., \& Khotimah, H. (2020). Pola Asuh Orang Tua Pada Anak Di Masa Pandemi Covid-19. Seminar Nasional Sistem Informasi, 2433-2441.

Dewi, W. A. F. (2020). Dampak COVID-19 terhadap Implementasi Pembelajaran Daring di Sekolah Dasar. EDUKATIF: JURNAL ILMU PENDIDIKAN, 2(1), 55-61. https:// doi.org/10.31004/edukatif.v2i1.89

Gubernur Provinsi Jawa Barat. (2020). Surat Edaran Gubernur Provinsi Jawa Barat Nomor 400/27/hukham

Tahun

2020.

Https://Covid19.Hukumonline.Com/2020/03/13/Surat-Edaran-Gubernur-ProvinsiJawa-Barat-Nomor-400-27-Hukham-Tahun-2020/.

Haerudin, Cahyani, A., Sitihanifah, N., Setiani, R. N., Nurhayati, S., Oktaviana, V., \& Sitorus, Y. I. (2020). Peran Orangtua dalam Membimbing Anak Selama Pembelajaran di Rumah sebagai Upaya Memutus Covid-19. Universitas Singaperbangsa Karawang, 3(1), 1-12.

Haerudin, D. A. . N. C. (2018). Penerapan Metode Storytelling Berbasis Cerita Rakyat Dalam Menanamkan Nilai-Nilai Karakter Anak. Jurnal Pelita PAUD, 3(1), 1-9. https:// doi.org/10.33222/pelitapaud.v3i1.420

Khasanah, D. R. A. U., Pramudibyanto, H., \& Widuroyekti, B. (2020). Pendidikan Dalam Masa Pandemi Covid-19. Jurnal Sinestesia, 10(1), 41-48. https://sinestesia.pustaka.my.id/journal/article/view/44

KPAI. (2021). Kekerasan Meningkat saat Pandemi Covid-19, Tumbuh Kembang Anak Terganggu. Https://Www.Kpai.Go.Id/Kanal/Informasi-Publik/Himbauan.

Kurniasari, A., Pribowo, F. S. P., \& Putra, D. A. (2020). Analisis Efektivitas Pelaksanaan Belajar Dari Rumah (Bdr) Selama Pandemi Covid-19. Jurnal Review Pendidikan Dasar: Jurnal Kajian Pendidikan Dan Hasil Penelitian, 6(3), 1-8.

Kusuma, W. S., \& Sutapa, P. (2020). Dampak Pembelajaran Daring terhadap Perilaku Sosial Emosional Anak. Jurnal Obsesi : Jurnal Pendidikan Anak Usia Dini, 5(2), 1635-1643. https:// doi.org/10.31004/obsesi.v5i2.940

Mastura, \& Santaria, R. (2020). Dampak Pandemi Covid-19 terhadap Proses Pengajaran bagi Guru dan Siswa. Jurnal Studi Guru Dan Pembelajaran, 3(2), 634.

Nafilah sri nagita. (2020). WHO Sebut Virus Corona Krisis Kesehatan Terburuk di Dunia, Ini Alasannya. Https://Health.Detik.Com/Berita-Detikhealth/d-5110552/Who-SebutVirus-Corona-Krisis-Kesehatan-Terburuk-Di-Dunia-Ini-Alasannya. 
Napitupulu, R. M. (2020). Dampak pandemi Covid-19 terhadap kepuasan pembelajaran jarak jauh. Jurnal Inovasi Teknologi Pendidikan, $7(1), \quad 23-33$. https://doi.org/10.21831/jitp.v7i1.32771

Pramana, C. (2020). Pembelajaran Pendidikan Anak Usia Dini (PAUD) Dimasa Pandemi Covid-19. Indonesian Journal of Early Childhood: Jurnal Dunia Anak Usia Dini, 2(2), 116-124. https://doi.org/10.35473/ijec.v2i2.557

Purwanto, A., Pramono, R., Asbari, M., Santoso, P. B., Wijayanti, L. M., Hyun, C. C., \& Putri, R. S. (2017). Studi Eksploratif Dampak Pandemi COVID-19 Terhadap Proses Pembelajaran Online di Sekolah Dasar. EduPsyCouns: Journal of Education, Psychology and Counseling, 2(1), 165-170.

Santrock, J. W. (2007). Child Development (8th ed.). McGraw-Hill.

Santrock, J. W. (2014). Life span development : Australia. In Erlangga (13th ed.). The McGrawHill Companies. https://ecu.on.worldcat.org/oclc/862301039

Sari, R. P., Tusyantari, N. B., \& Suswandari, M. (2021). Dampak Pembelajaran Daring bagi Siswa Sekolah Dasar Selama Covid-19. Prima Magistra: Jurnal Ilmiah Kependidikan, 2(1), 9-15. https:// doi.org/10.37478/jpm.v2i1.732

Suhendro, E. (2020). Strategi Pembelajaran Pendidikan Anak Usia Dini di Masa Pandemi Covid-19. Golden Age: Jurnal Ilmiah Tumbuh Kembang Anak Usia Dini, 5(3), 133-140. https://doi.org/10.14421/iga.2020.53-05

WHO. (2019). Coronavirus disease (COVID-19) pandemic. Https://Www.Who.Int/Emergencies/Diseases/Novel-Coronavirus-2019. 